\title{
Execution of Anti-Poverty Sub-Plan---A Case Study of Digambarpur Gram Panchayet, Patharpratima Block, South 24 Parganas District, West Bengal
}

\author{
Manjira Adhikary* and Dr. Sandipan Chakraborty** \\ *SRF, UGC; ** Associate Professor, Presidency University, Kolkata, West Bengal, India
}

\begin{abstract}
Poverty is the condition where the basic needs of people, i.e. food, clothing and shelter are not available uniformly. Poverty, when considered as a relative term, it shows the difference in standard of living as well as economic and socio-cultural disparity among the people in a society. Panchayeti Raj Institutions are implementing various poverty alleviation programmes as well as some important social security programme with an objective to 'Usher Economic Development' and 'Social Justice'. One of the major objectives from these interventions is that every individual living within the respective areas of a Gram Panchayet may remain totally free from hunger and is generally above the level of destitution. One such attempt has been taken by the Digambarpur Gram Panchayet (GP) of Patharpratima block, South 24 Parganas, West Bengal to reduce the differences in existing socio-economic situation by assisting the destitute people. Total 117 respondents are selected from the sampled households for assistance based on Rural Household Survey (RHS). The various types of assistance were supplied from the local self government funded both by different government departments, as well as personal initiatives. The objectives of the present paper is primarily to reveal the nature and status of socio-economic boosting especially to eradicate the poverty and to enhance the standard of living as a part of maintaining healthy society based on the attempt of the GP. The study is regarding execution of the 'Sahai sub-plan' in the GP at Gram Sansad (GS) level and its success story. The data is based on a report obtained from the GP itself and certain other information obtained primarily from the GP through interviews of the village people.
\end{abstract}

Keywords: Sahai sub-plan, destitute, Gram Panchayat (GP), Gram Sansad (GS).

\section{Introduction}

Our society, whether it is rural or urban, is a typical mix-up of people belonging to various income groups. Some live in prosperity whereas others are below the level of destitution. They do not own even the bare necessities of life, i.e. food, shelter and clothing. Development of such region thus requires bringing equity and balance in standard of living. Panchayati Raj Institutions (PRIs) have thus thought of several poverty alleviation schemes and other social programmes to help the poor people augment their standard of living which in the long run helps in achieving overall development of the region. These are policy interventions which are initiated at the Gram Panchayets (GP) so that there are no people within the GP who do not have food for living, clothes to wear and shelter (Misra, Suresh, 2002). Funds for this scheme come both from different Government departments as well as people's contribution. This signifies people's participation in the programme and their earnest interests to help these destitute overcome their poor situation. The present study is regarding one such scheme which is known as anti-poverty sub-plan, better known by the name, SAHAI-anti-poverty sub-plan. SAHAI or "State Action Against Hunger and Inequality" is a scheme which is executed at the Gram Sansad (GS) village parliament level. It is not a supply driven scheme. This long-term scheme is executed following a particular procedure on the basis of demand of the concerned region. The following paper highlights upon execution of the SAHAI sub-plan in Digambarpur gram Panchayet of Patharpratima block, South 24 Paraganas District, West Bengal. According to the Rural Household Survey (RHS) in West Bengal (2005-06), 3.58\% of population (480250 families) does not have the ability to gain at least one meal a day. Another $11.54 \%$ of population (1545473 families) does not have the certainty of gaining two square meals a day. This shows the necessity of the SAHAI sub-plan in the state, basically at the GP level. The paper thus concerns upon execution of the sub-plan at Digambarpur GP. Total 117 respondents from 83 families were selected for this purpose. Identification of the poor has been done on the basis of Rural Household Survey. Individuals were selected depending on the fulfillment of certain criteria mentioned by West Bengal Panchayet and Rural Development Department (WBPRD). 


\section{Study Area:}

The present study on Digambarpur Gram Panchayet of Patharpratima block, South 24 Parganas. The GP is located at the northernmost tip of the block. Hence it is more close to the mainland. The GP has 8 mouzas with 15 Gram Sansads (GS). The mouzas are, Ramnagar Abad, Indranarayanpur, Parbatipur, Uttar Mahendrapur, Paschim Sridharpur, Gurudaspur, Digambarpur and Dakshin Durgapur. The GSs are the basic unit of study in the present paper. Gram Sansad or village Parliament are small political units which act as recommending bodies of the GP and plays a very significant part in decision making. The following table will give an idea of mouza wise distribution of the GSs (table 1, Fig. 1).

\begin{tabular}{|l|l|}
\hline Gram Sansad Number & Name of the mouzas \\
\hline $1,2,3,4$ & Dakshin Durgapur \\
\hline $5,6,8,9$ & Digambarpur \\
\hline 7 & Gurudaspur \\
\hline 10 & Paschim Sridharpur \\
\hline 11 & Uttar Mahendrapur, Parbatipur \\
\hline 12,13 & Indranarayanpur \\
\hline 14,15 & Ramnagar Abad \\
\hline
\end{tabular}

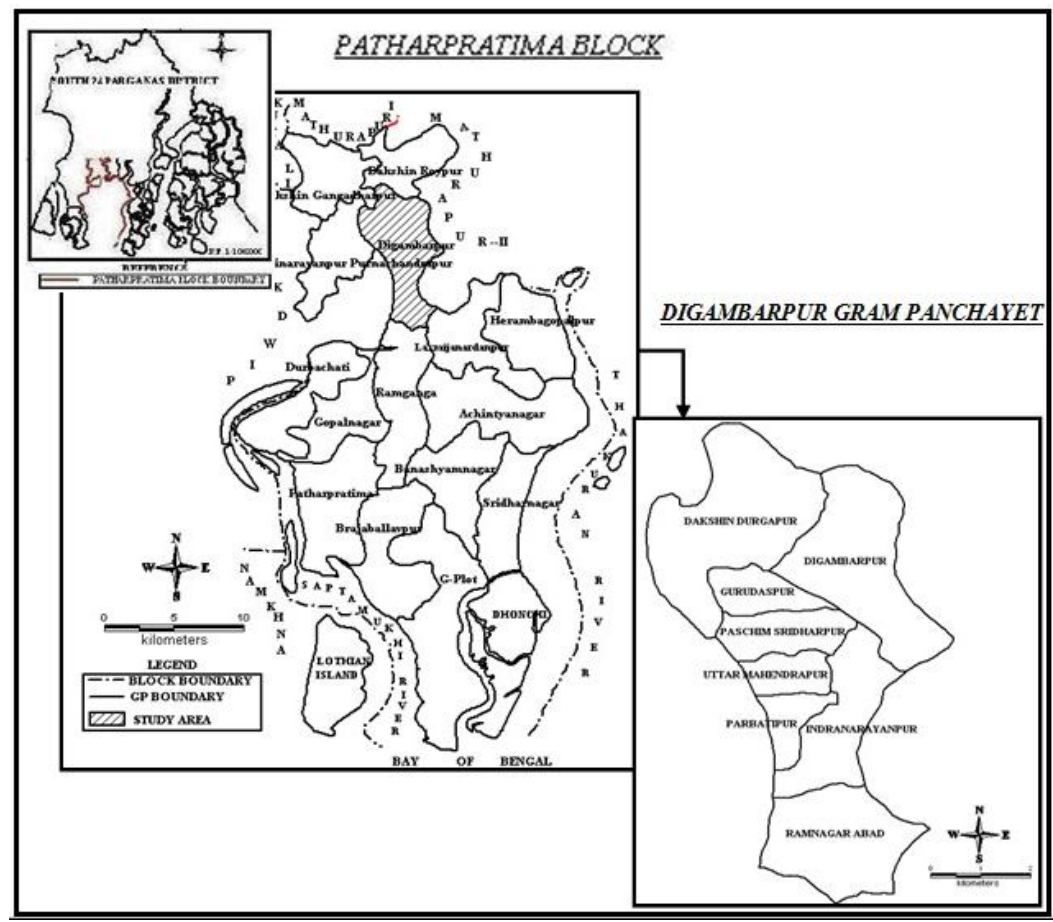

Table 1: Showing mouza wise distribution of Gram Sansads Compiled from DPMS, NATMO; Census Atlas, Govt. of India Fig: 01- Location of the Study area

\section{Objectives:}

The objective of my paper is to find out how the scheme is executed at the GP, and have an overview of the types of assistances provided to the people. The assistances thus provided by the scheme are not equally available at all the Gram Sansads (GS). Thus my objective is also to find the status of the GSs according to the availability of the assistances. However, the objectives of my study can be summarized as follows:

- To find out how the sub-plan is executed.

- To overview the types of assistances.

- $\quad$ To reveal the mode of execution of SAHAI local area development plan, and

- $\quad$ To find out the status of the Gram Sansads according to the availability of assistances.

\section{Materials And Methods:}

The entire study, analysis and inferences are based on the community development report obtained from Digambarpur GP and certain other related data collected primarily from the GP. As the study is regarding a particular scheme, a brief idea of the scheme has been provided followed by its applicability in the GP. Data 
analysis part includes analysis of various data thus extracted regarding execution of the scheme, beneficiaries of the scheme and funding details of the scheme. The data thus obtained is Gram Sansad wise. Henceforth the analysis and interpretations has been drawn Sansad wise in details as available. However the entire methodology of the study can be categorized under the following three heads:

- $\quad$ Pre-field work: This includes the observation and validation of study area and preparation of base map and subsequent collection of required literature regarding the scheme and policy of the study area itself.

- $\quad$ Field work: Collection of reports and relevant data, information, from the GP office and confirmation of the ground truth in relation to data received through interviewing the village people. Specific interview has been carried on for the final settlement of the scheme.

- $\quad$ Post-field work: Proper tabulation, analysis, presentation of data and resultant maps and diagrams for getting inferences and possible suggestions.

\section{Results And Discussion:}

As already mentioned before, SAHAI sub-plan is an Anti-poverty sub plan executed at the GP level. The SAHAI sub-plan is for those people who are unable to do any type of work, people who are completely jobless due to sickness and mainly for those women who are either divorcee or abandoned by their husband or socially deprived due to some other causes. The scheme gives aid to those people who are physically or mentally handicapped, beggars, exteremely aged people and also the orphans. Beside these it should also be mentioned that this scheme never includes those people as the beneficiaries who does not work due to lack of suitable job options and the people who have got used to begging. The scheme also excludes those families which bear the only character of being poor compared to that of the other families in the village. The people are selected on the basis of certain predefined criteria (here, indicator of food security and six other indicators mentioned by the Panchayet and Rural Development Department). The Block Development Office generates a primary list of SAHAI families depending on the score obtained by them in the Rural Household survey, which is sent to the GP. GP will now verify the exact situation of the short listed families with the help of Gram Unnayan Sabha and the SAHAI Bandhus (people representing the Self Help Groups), selected by the GP. Those families will be excluded by the GP who are found to be not that very destitute in spite of being selected in the first list. In the Panchayet area, some families might be left behind during the survey; GP will assist them with minimum assistance and will take initiative to bring them within the benefits of next RHS. Now the final list of SAHAI families will be prepared on behalf of the GP along with Gram Unnayan Sabha and the SAHAI Bandhus. If there is any new recommendation for inclusion in the list, then that can be made by Gram Unnayan Sabha only which will be finalized bye the above mentioned procedures. Finally the ultimate list of the families will be prepared by the GP in a meeting of the Gram Sansad. It is a rule to write up this final list in any open space/on wall at GP office or GS, to bring it in everybody's knowledge. The scheme receives fund both from Government bodies as well as from people's contribution. The Government bodies who fund the scheme are, District Rural Development Cell (DRDC) \& Zilla Parishad (ZP), the Community Development Block (CD Block), Backward Region's Grant Fund (BRGF) and the GP fund. The scheme looks after well-functioning of the already running schemes like, Antyodaya Anna Yojana, Annapurna Anna Yojana, National Social Assistance Programme, and National Rural Employment Guarantee Scheme. Assistances regarding bare necessities of life i.e. food clothing and shelter, all are provided under this scheme. The scheme also provides assistances for infrastructural facilities like house building and sanitation. The scheme also extends loan and job opportunities to the people for earning a living. People are also given livestock to start business of livestock rearing on their own (Guidelines for Programme on SAHAI, Panchayet and Rural development Department, Government of West Bengal, 2007).

\section{Application of the Scheme at Digambarpur GP:}

Overall development of any region signifies development of backward class people and establishment of social justice. Keeping this in mind, primarily women from BPL (Below Poverty Line) families were selected by the GP to form the SGSY (Swarna Jayanti Gram Swarojgar Yojana) groups. At present there are 219 such SGSY groups at Digambarpur GP. These SGSY Groups have their representative groups in 15 Gram Sansads. These sub-groups have grouped together to form the Sarada Sangha (estd.28/01/2009). Since then the Sangha has been functioning actively along with the GP in ushering development in the region. The SAHAI sub-plan is one of the many schemes running in this GP.The SAHAI sub-plan was started in this GP on 18/06/2009. Execution of this SAHAI sub-plan could not have been possible without the assistance of Sarada Sangha. Total 117 people from 83 families were the selected beneficiaries for this scheme. These families are given most possible livelihood facilities and cooked food for their assistance. Besides this, medical, educational, and other socio-economic assistance are also provided for better well-being and to maintain better socio-economic panel. Fund for this scheme mainly comes from different government departments, but a certain amount is also collected from the people residing locally. During any workshop or awareness programmes at the GP, fund 
raising programmes are also held, which results in collection of a good amount. With the help of this locally collected fund, various home appliances, amenities, garments and several other materials are given for boosting the socio-economic status of the people. Not only this, SAHAI scheme also supervises proper functioning of the existing schemes and has initiated certain programmes which leads to proper utilisation of human resources. One such programme includes involvement of divorcee, abandoned and destitute women into forming Self Help Groups, which helps them in earning their food, dress and shelter and other necessary goods and there also occurs proper utilisation of human resources (SAHAI Poverty sub-plan, Digambarpur Gram Panchayet, 2011-12). So far as the study is concerned, the Digambarpur Grampanchyet is the major beneficiary and out of 15 Gram Sansad most of them are getting facilities from this scheme. Out of total incumbents, there are 117 beneficiaries, from which 36 are male and 81 are female beneficiaries. So it is clearly seen that female are given more priority in this scheme compared to that of the males, and another most significant criterion is that the helpless Women are getting more priority among the beneficiaries. Female beneficiaries mainly include widows,

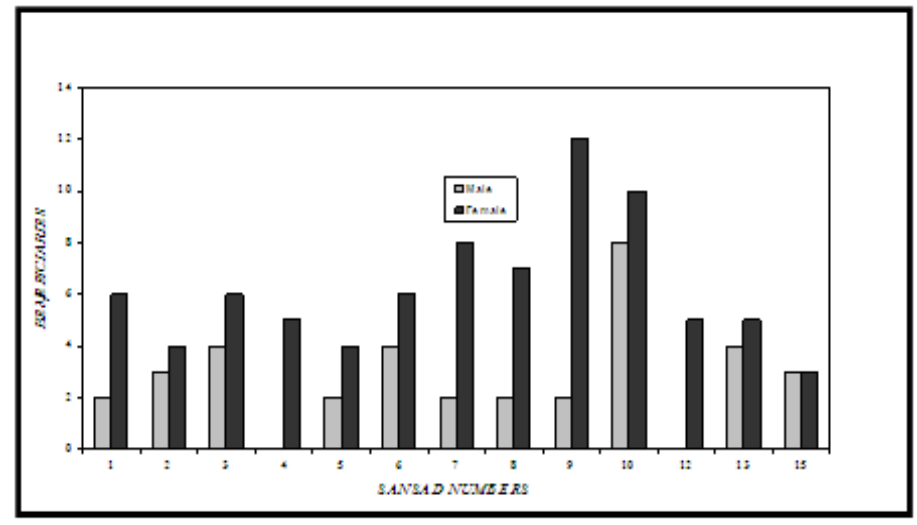

Fig.2 Sansad wise distribution of total number of male and female beneficiaries

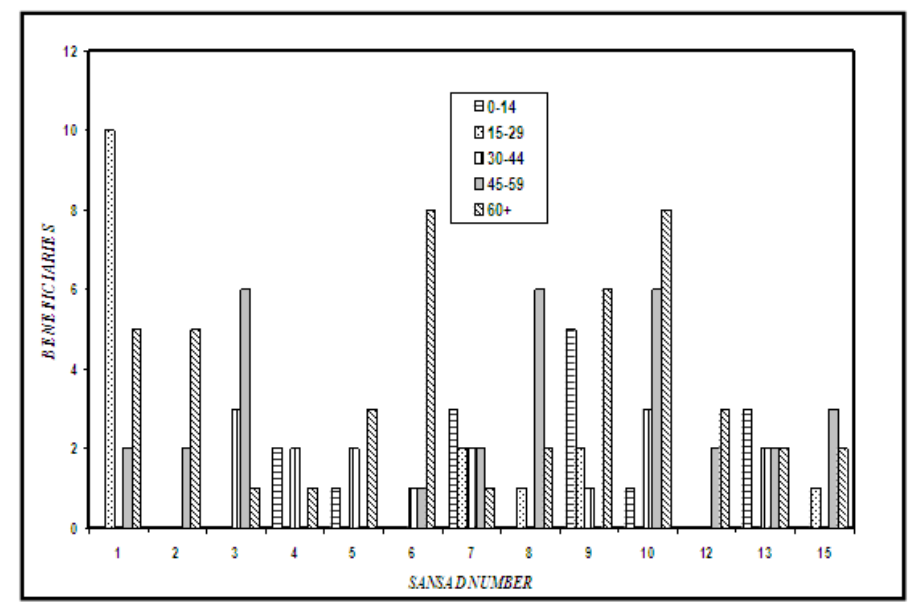

Fig-3. Sansad wise age-group of beneficiaries

abandoned women mentally/physically handicapped ones and the extremely aged ones. The Sansad-wise distribution of male and female beneficiaries is shown in a diagram (fig. 2).

People of various age groups are also considered as most suitable for receiving benefits from the scheme which reveals that the scheme is only for those who are barely in need of help in the society, no matter what the age is. Starting from 6 years of age, 87 year old people are also given assistances under this scheme for their well-being. The beneficiaries (both male and female) have been categorized into several age groups in order to have a better idea about the beneficiaries and the Sansad-wise distribution of the beneficiaries of the particular age-groups has been revealing some significant outcome from this analysis (Table and fig.3). The 60+ age group has the highest number of beneficiaries, which is 47 . Next highest number of beneficiaries is in the 45-59 age groups, which is 32. 30-44 age groups have 16 beneficiaries and 15-29 and 0-14 age groups have 7 and 15 beneficiaries, respectively. The 0-14 age group include children who are either orphan or do not have any one in the family who has the ability to earn a living. It has been assigned that the scheme gives support to various categories of people depending on their needs. The graphical representation of the various categories of beneficiaries (fig 4) gives a better idea of the distribution. The widow, divorcee and abandoned category include female beneficiaries only, whereas the rest of the categories have both male and female beneficiaries. The 
'others' category includes people who do not have any earning member in the family, and they themselves are also unable to do any type of jobs and also the orphans. The SAHAI sub-plan assists the beneficiaries by giving several assistances. The assistances provided by the scheme at Digambarpur GP are,

(i) Cooked food, two times a day (long term basis)

(ii) Money for buying clothes for the whole year (one-time)

(iii) Money for house repairing (one-time)

(iv) Buying plot of land for house building

(v) Buying mosquito net and mat for bringing development in health facilities. (one- time)

(vi) Money for hospital charges and life-saving drugs (one-time)

(vii) Suitable type of assistance for earning livelihood

(viii) Money for buying books, pen and copies

The first two assistances are given to all 117 people, but the rest of the six are given only to certain selected beneficiaries. The following table and the corresponding graph will give an idea about the total number of beneficiaries per assistance, Sansad-wise (Table-2, Fig. 5).

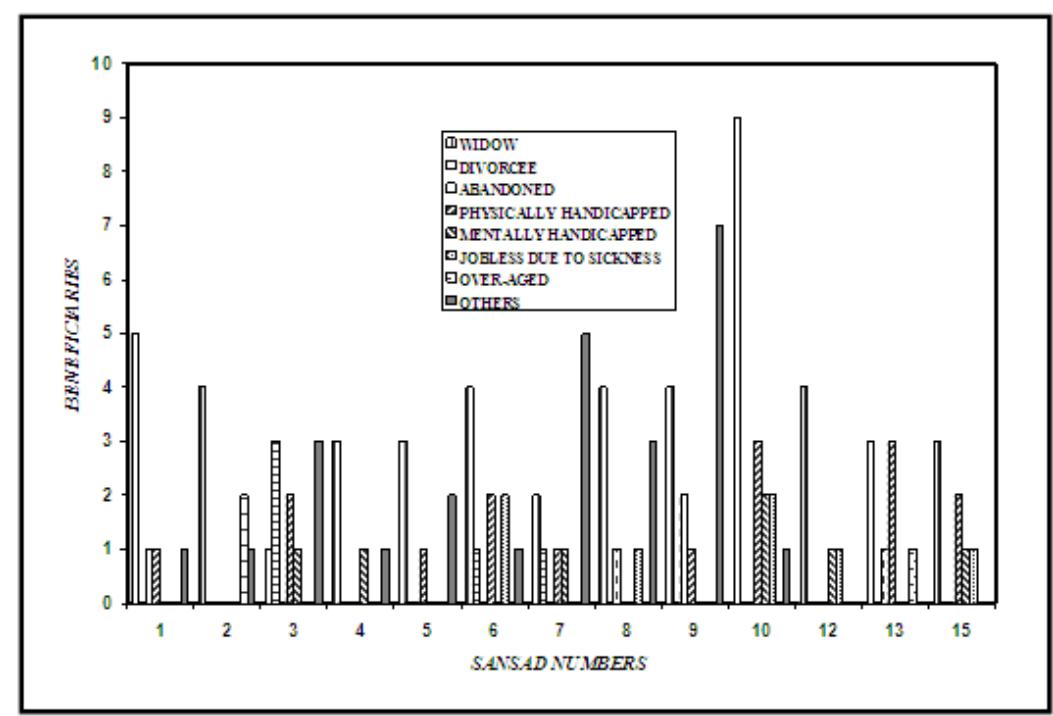

Fig: 4 Sansad wise categories of beneficiaries

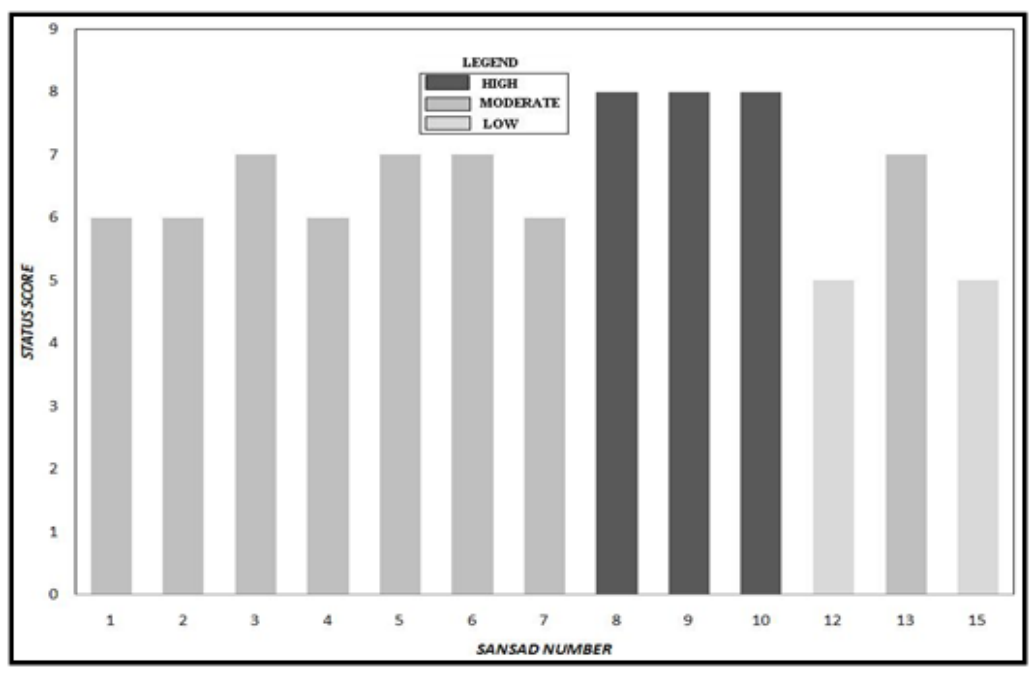

Fig. -5 Status classes of the Gram Sansads 


\begin{tabular}{|c|c|c|c|c|c|c|c|c|}
\hline \multirow{2}{*}{ Sansad number } & \multicolumn{7}{|c|}{ Types of Assistances** } \\
\cline { 2 - 11 } & (i) & (ii) & (iii) & (iv) & (v) & (vi) & (vii) & (viii) \\
\cline { 2 - 11 } & \multicolumn{7}{|c|}{ Number of Beneficiaries per assistance } \\
\hline 1 & 8 & 8 & 5 & 0 & 6 & 6 & 6 & 0 \\
\hline 2 & 7 & 7 & 3 & 0 & 6 & 3 & 4 & 0 \\
\hline 3 & 10 & 10 & 4 & 0 & 7 & 4 & 4 & 1 \\
\hline 4 & 5 & 5 & 3 & 0 & 3 & 3 & 0 & 2 \\
\hline 5 & 6 & 6 & 4 & 0 & 4 & 4 & 1 & 2 \\
\hline 6 & 10 & 10 & 5 & 0 & 7 & 7 & 2 & 7 \\
\hline 7 & 10 & 10 & 3 & 0 & 3 & 3 & 0 & 3 \\
\hline 8 & 9 & 9 & 4 & 1 & 6 & 6 & 6 & 1 \\
\hline 9 & 14 & 14 & 9 & 2 & 6 & 9 & 6 & 2 \\
\hline 10 & 18 & 18 & 16 & 3 & 17 & 17 & 4 & 6 \\
\hline 12 & 5 & 5 & 0 & 0 & 5 & 5 & 4 & 0 \\
\hline 13 & 9 & 9 & 4 & 0 & 4 & 4 & 3 & 2 \\
\hline 15 & 6 & 6 & 5 & 0 & 5 & 5 & 0 & 0 \\
\hline Total no. of \\
beneficiaries
\end{tabular}

Table- 2- Sansad-wise total number of beneficiaries per assistance. ** (i) to (viii) mentioned earlier

The above table and the corresponding bar diagram (fig.5) clearly depicts that all the assistances are not available to all the Gram Sansads. An attempt has been taken to find out the status of the Gram Sansads depending on the availability of the particular assistances. Gram Sansad with the presence of the assistance has been scored 1 , and absence of any assistance has been scored 0 . In total there are 8 types of assistances. Hence, the highest score should come, 8 , which means availability of all the assistances. The Gram Sansad has been ranked according to the cumulative score as obtained by each of them depending on the availability of the particular assistances. The following table shows the ranks of the Gram Sansads (Table 3).

Table 3: Composite Score of the Gram Sansads depending on availability of the assistances

\begin{tabular}{|l|l|l|l|l|l|l|l|l|l|}
\hline \multirow{2}{*}{$\begin{array}{l}\text { Sansad } \\
\text { numbe } \\
\text { r }\end{array}$} & \multicolumn{6}{|c|}{ Availability/Non-availability of the assistances } \\
\cline { 2 - 10 } & (i) & (ii) & (iii) & (iv) & (v) & (vi) & (vii) & (viii) & Cumulative Score \\
\hline 1 & 1 & 1 & 1 & 0 & 1 & 1 & 1 & 0 & $\mathbf{6}$ \\
\hline 2 & 1 & 1 & 1 & 0 & 1 & 1 & 1 & 0 & $\mathbf{6}$ \\
\hline 3 & 1 & 1 & 1 & 0 & 1 & 1 & 1 & 1 & $\mathbf{7}$ \\
\hline 4 & 1 & 1 & 1 & 0 & 1 & 1 & 0 & 1 & $\mathbf{6}$ \\
\hline 5 & 1 & 1 & 1 & 0 & 1 & 1 & 1 & 1 & $\mathbf{7}$ \\
\hline 6 & 1 & 1 & 1 & 0 & 1 & 1 & 1 & 1 & $\mathbf{7}$ \\
\hline 7 & 1 & 1 & 1 & 0 & 1 & 1 & 0 & 1 & $\mathbf{6}$ \\
\hline 8 & 1 & 1 & 1 & 1 & 1 & 1 & 1 & 1 & $\mathbf{8}$ \\
\hline 9 & 1 & 1 & 1 & 1 & 1 & 1 & 1 & 1 & $\mathbf{8}$ \\
\hline 10 & 1 & 1 & 1 & 1 & 1 & 1 & 1 & 1 & $\mathbf{8}$ \\
\hline 12 & 1 & 1 & 0 & 0 & 1 & 1 & 1 & 0 & $\mathbf{5}$ \\
\hline 13 & 1 & 1 & 1 & 0 & 1 & 1 & 1 & 1 & $\mathbf{7}$ \\
\hline 15 & 1 & 1 & 1 & 0 & 1 & 1 & 0 & 0 & $\mathbf{5}$ \\
\hline
\end{tabular}

\section{Source: Computed by the authors}

Depending on the composite scores obtained by the Gram Sansads, They have been categorized into three status classes, High, Moderate and Low. The following tables show status classes of each Gram Sansad (Table 4.) and also total number of gram Sansads per status class (Table- 5, Fig- 5). The relevant extraction, analysis and representation state that high status class has the highest number of frequencies i.e. highest number of Gram Sansads, which are, 7. Moderate class has 4 Gram Sansads and Low status class having only 2 Gram Sansads. Besides all the above mentioned assistances the sub-plan also takes care of certain other facilities like:

- Recommendation for BPL card (for the financial year 2011-2012, for 50 people).

- Respective recommendation for widow (IGNWPS) and Old age (IGNOAPS) pensions (for the financial year 2011-2012, for 16 and 18 people respectively). 
Table- 4- Status classes of the Gram Sansads

\begin{tabular}{|c|c|c|}
\hline Sansad Number & Total number of available assistances & Status Classes \\
\hline 1 & 6 & Moderate \\
\hline 2 & 6 & Moderate \\
\hline 3 & 7 & High \\
\hline 4 & 6 & Moderate \\
\hline 5 & 7 & High \\
\hline 6 & 7 & High \\
\hline 7 & 6 & Moderate \\
\hline 8 & 8 & High \\
\hline 9 & 8 & High \\
\hline 10 & 8 & High \\
\hline 12 & 5 & Low \\
\hline 13 & 7 & High \\
\hline 15 & 5 & Low \\
\hline
\end{tabular}

Table- 5- Total number of Sansads in each status class

\begin{tabular}{|c|c|}
\hline Status Classes & Total number of Sansads \\
\hline High & 07 \\
\hline Moderate & 04 \\
\hline Low & 02 \\
\hline
\end{tabular}

Source: Computed by the authors

\section{Findings And Conclusion:}

The above study shows the outcome of the execution of the sub-plan at Digambarpur Gram Panchayet. It was found that number of female beneficiaries is more compared to that of the male beneficiaries. Both poor and physically impaired people are given equal assistances. Though all facilities are not available to all the categories of people, all of them are given assistances regarding the basic requirements of food, shelter and clothing. This ensures one fact that all the people in the GP are having two meals a day, which is an achievement on the GP's part. People of all age groups are benefited by the scheme according to their needs. People with age, 60 years and above are given special attention under this scheme, which ensures the success and inevitability of this scheme.

This is the outcome of observations based on the report obtained from the Block Development Office and interviewing the GP staffs of Digambarpur GP. Alongside this, a primary survey was also done in the concerned GP regarding the actual scenario of the execution of the sub-plan at the GP. Almost all the Sansads area was visited and it was observed that there were many people at the villages who are not aware of the scheme. There were many of them who barely need the help but are not even contacted on the behalf of the GP. Many people also complained that mainly those people were included within the beneficiary list of the scheme that was either known to the Sahai Bandhus or the GP staffs. This thus has resulted into a partial inclusion of beneficiaries and thus a partial success of the scheme at large.

It has been assigned that all the members of study area not enjoying the benefits of this scheme. So, if all people are engulfed with this scheme more people will be benefited. This in the long run will lead to the betterment of the situation of Digambarpur GP. Likewise, if such initiatives are carried out in other GPs, it will be of great help to the poor people and to the society as a whole.

\section{References:}

[1]. Guidelines for SAHAI Programme, (2007). Panchayet and Rural development Department, Government of West Bengal, (2007).

[2]. Handbook of Rural Development Programmes in India, (2011 - 12), Govt. of India

[3]. Hemanta Saikia, Prodip Kumar Adhyapok, 2013, LAP Lambert Academic Publishing, Rural Development in India

[4]. K. R. Gupta, 2009, Rural Development in India (Vol. 1) 01 Edition, Atlantic Publishers,

[5]. Katar Singh, (2009). Rural development: Principles, Policies and Management, $3^{\text {rd }}$ edition, Sage Publications India Pvt. Ltd.

[6]. Misra, Suresh (2002): New trends in community initiatives: Panchayets in action; Journal of Rural Development; Vol. 21 No. 3 , National Institute of Rural Development, Hyderabad, pp. 395-410

[7]. Report on SAHAI Poverty sub-plan-(2011-12), --Digambarpur Gram Panchayet, Patharpratima, S. Twenty four Parganas,

[8]. Thulasiram Gundluru, Muralidhar B. V. , 2013, Co-operatives and Rural Development in India 1st Edition, New Century Publications

[9]. Sahu, B K. 2003, Rural Development In India, 01 Edition, Anmol Publication, Delhi 